\title{
A media framing analysis of urban flooding in Nigeria: current narratives and implications for policy
}

\author{
Olalekan Adekola $^{1}$ (D) Jessica Lamond ${ }^{1}$ \\ Received: 13 March 2017 / Accepted: 8 November 2017 / Published online: 21 November 2017 \\ (C) The Author(s) 2017. This article is an open access publication
}

\begin{abstract}
A critical element of current flood management is the importance of engaging key policy actors when policy decisions are to be made. However, there is still only limited understanding of how narratives of flood management actors may influence flood management policies, even though there is a suggestion that actors can strategically use their narratives to influence policy directions. In a developing country like Nigeria, there are still questions around lessons that can be learnt from understanding the narratives of policy actors, to unravel the complex nature of strategies and policy directions in managing urban floods. To help fill these gaps, this paper uses quantitative content analysis to explore the frame of five policy actor groups (government, local communities, business, multilateral organisations and non-governmental organisations (NGOs)) as expressed in local and national newspapers between 2012 and 2016 to understand their narratives of causes and strategies to solve the problem of urban flooding in Nigeria. The narratives of government, local communities and businesses align with the premise that flooding can and should be prevented whilst that of multilateral and business actors champion adaptation strategies on the basis that flooding is
\end{abstract}

Editor: Chinwe Ifejika Speranza.

Electronic supplementary material The online version of this article (https://doi.org/10.1007/s10113-017-1253-y) contains supplementary material, which is available to authorized users.

Olalekan Adekola

lekan.adekola@uwe.ac.uk

Jessica Lamond

jessica.lamond@uwe.ac.uk

1 Centre for Floods Communities and Resilience, University of the West of England, Frenchay Campus, Coldharbour Lane, Bristol BS16 1QY, UK inevitable and hence more energy should be directed at 'living with water'-emergency response, damage reduction and the aftermath. The study also identified areas of potential consensus and conflict between direct actors such as government and local communities on the one hand and funders on the other. Better discussion among actors aiding understanding of contemporary thinking and local realities will aid policy-making and policy implementation in the Nigerian context. An important step will be in the collaborative design of an urgently needed 'Nigerian policy on flooding' which currently does not exist.

Keywords Content analysis · Developing countries ·

Discourse $\cdot$ Infrastructure $\cdot$ Narratives

\section{Introduction}

Over the last three decades, there has been an increase in the number and severity of flood events in many urban areas of Africa (Ajibade et al. 2013; Jalayer et al. 2015), causing social, economic and environmental impacts (Adelekan 2010; Douglas et al. 2008; Lwasa 2010). In Kampala, for example, flood resulting in the collapse of urban drainage system increased from five events in 1993 to ten in 2014 (Mugume et al. 2017). In 2012, Nigeria, the most populous country in Africa, experienced one of its largest floods in a century (Mmom and Aifesehi 2013) causing the destruction of assets worth over US $\$ 9.5$ billion, most of which were in the urban centres (Federal Government of Nigeria 2013). This incident has increased the interest of relevant actors including local communities, government and donor agencies in urban flooding risk management issues. For instance, a Flood Relief and Rehabilitation committee was established with membership drawn from corporate, government, religious, non- 
governmental and multilateral organisations (Federal Government of Nigeria 2013). The Lagos State Government through its Ministry of the Environment has developed a drainage master plan as part of proactive measures to tackle the menace of flooding in the state (Oshodi 2013). However, in Nigeria as in other contexts, flood policy is still generally a contested arena among actors, bringing about in particular debates around appropriate strategies for flood management (Ford et al. 2015; van der Werff 2004).

Following the 2012 flood, media coverage of flood-related issues increased in the Nigerian news media. In such circumstances, news media became not just a vehicle for informing the public but an important arena for debate and an avenue for contextualising and understanding flood events (Bohensky and Leitch 2014; Hansen 2010). As pointed out by McNair (2009), the media is not value-free but what is written within it influences public perception and the policy process (Doulton and Brown 2009). Similarly, scholars have shown that policy actors can use the media to (in)directly shape policy processes and outcomes (Crow and Lawlor 2016; Robinson 2001). Therefore, examining the public content of actors' narratives as framed within media articles provides insights not only into the broad perceptions of actors but into also why some practices may dominate or be undermined in the policy arena.

This perspective has recently sparked a fertile area of research in respect of media framing around recent flooding events to understand policy (Bohensky and Leitch 2014; Devitt and O'Neill 2017; Escobar and Demeritt 2014; Haider-Markel et al. 2007). However, the majority of these studies are for cities in developed regions, whilst far less is known about how flooding issues are framed within local and national media in developing countries and the consequent policy implications. Whilst there has been a relatively small body of literature investigating media and climate change in Nigeria (Akpan et al. 2012; Ukonu et al. 2012; Uzochukwu et al. 2014), there has been no previous analysis of how issues of urban flooding are framed within the Nigerian media, especially by key policy actors. Inadequate analysis has clouded the picture of not only what policies and strategies are being adopted but also how these are designed and what underlying guiding assumptions/principles are directing flood management decisions in the present and future. Understanding and potentially challenging these assumptions can help ensure that flood management strategies are sustainable and do not further degrade infrastructure and exacerbate poverty and social unrest (Eriksen et al. 2011). This is a significant evidence gap, especially now that flood management is a high priority on the political and policy agenda in Nigeria (Nkwunonwo et al. 2016) and many African countries (Di Baldassarre et al. 2010; Van Koppen 2003).

This study is driven by three major research questions: (1) What are the dominant frames used by the main actors in framing flood issues in Nigeria?; (2) How has this changed over the years since 2012?; and (3) What are the possible policy implications of the manner in which various actors frame urban flood issues? This paper follows a growing body of literature investigating flooding and the media (Bohensky and Leitch 2014; Devitt and O'Neill 2017; Rinne and Nygren 2016). However, this research differs from previous studies not only in focusing on a new case in Nigeria but in disaggregating articles based on the frames used by actors and not necessarily the framing by reporter/journalists. Thus, we have made a distinction between a media frame by the journalist and the frame used by a policy actor group within a media report. Of the research that has been done on the broader spectrum of media and flooding issues, this appears to be the first seeking to tease out difference in key policy actors' frames. Given that flood management policy often brings together a range of state and non-state actors often with varied and evolving interests, understanding how various actors see the issue differently given one frame or the other is a worthwhile pursuit.

\section{Context}

\section{Nigeria: flooding, urbanisation and urban infrastructure} in Nigeria

Since the end of the Nigerian civil war and accompanying oil boom of the 1970s (Orubuloye 1995), the country has become increasingly an urban society and the proportion of people living in urban areas has gradually increased from $16 \%$ in 1970 to more than $20 \%$ in 1980 (Metz 1991) and is currently over 46\% (The World Bank 2016). According to The World Bank (2016), urban population stands at 83 million with over $15 \%$ of the country's population living in urban agglomerations of more than one million people. Nigeria's urban population is expected to continue to grow relatively fast in the coming decades (Jiang and O'Neill 2017).

Historically, Nigeria's urban centres have experienced occasional major floods, for example, there is oral history record of water flooding some major cities (Tremearne 1910). Although studies have documented flooding incidents that occurred more recently (Bashir et al. 2012; Ugonna 2016), for example, the 2011 flood that mostly affected the south western cities of Lagos and Ibadan, they did not gain much national attention. Thus, the entire country was unprepared for the 2012 flood, which ravaged the majority of cities in the north and south of the country. This flood is regarded as the most catastrophic the country has witnessed in modern history (Mmom and Aifesehi 2013). The 2012 flood impacted 33 of 36 states in the country, including 14 that were considered severely affected (Federal Government of Nigeria 2013). A total of 37 million people were impacted and the disaster displaced 2.1 million, killed 363, left over 18,200 injured 
and destroyed or damaged more than 618,000 houses (International Federation of Red Cross and Red Crescent Societies 2013; United Nations Office for the Coordination of Humanitarian Affairs 2012).

Flooding is clearly partly driven by climate-related factors, and projections are that urban flooding will worsen as Nigeria's climate is likely to see growing shifts in temperature, rainfall, storms and sea levels throughout the twenty-first century (Abiodun et al. 2011). Urban floods are not only accompanied by loss of lives and properties but also damage to crucial infrastructure, which leads to the disruption of socioeconomic activities and, in some cases, temporary or permanent displacement of people. Thus, the need to sustainably manage floods in Nigerian urban centres is even more pressing considering the challenging problems of inadequacy and deterioration of urban infrastructure (Ogu 2009) and poverty facing urban residents (Babanyara et al. 2010). This is even more worrying when the resultant effects of flooding have a strong impact on lives, affect the cost of doing business in a city and lead to a less egalitarian society (Adeyemi et al. 2015). The majority of urban infrastructure (such as roads, railways, etc.) in many Nigerian cities (except for new cities like Abuja) was laid during the pre-independence era and was not designed to meet the day-to-day challenges of modern urban populations let alone stand any major flooding due mainly to the fact that infrastructures are under-designed. Moreover, much of the infrastructure has reached the end of its design life and is deteriorating without being replaced.

Thus, the poor state of infrastructure in cities is now a major source of worry whenever it rains. The situation is such that residents have not entirely recovered from preceding flooding before another incident occurs. In many instances, socio-economic efforts designed to ameliorate impacts can take years to be realised. For instance, in 2015, victims of the 2012 flood were yet to receive housing promised to them (Wantu and Akubo 2015) and it is doubtful if they ever will (Gwaza 2014).

\section{Cause(s) of flooding}

Contemporary discussions around flooding are often characterised by considerable debate and, sometimes, conflict (Hutter et al. 2014). Fundamental to these debates or discursive 'battles' are questions over whether anthropogenic or climate-related factors are the root cause of flooding (Texier 2008; Thompson and Warburton 1985) and illustrate the potentially complex interactions between human and the environment. Often underlying such argument is a lack of distinction between causative factors, driving forces and impacts. In hydrological terms, flooding is a natural phenomenon (Fleming 2002), mostly a result of extreme weather and climate events. However, to other actors in the public who may struggle with the nuance between something causing flooding and the presence of something, which exacerbates the impacts of flooding, focus may extend to underlying human activities and behaviour. As such, flooding is not always only caused by climatic conditions but its interactions with socio-political factors, e.g. infrastructure and management. Thus, actors may perceive that if some human factors were not present, flooding would not occur, irrespective of the quantity of rainfall. Whilst our intention is not to discuss the veracity of these claims, we do believe that the way an actor perceives the root cause of flooding will have an impact on the way it is framed and the strategies advanced as solutions (van Eeten 1997). It has been suggested that the way we frame an issue is a reflection of our perception (Kahneman and Tversky 1984); as such, our frames are hardly 'innocent' but a reflection of our values (Steinberg 2007). In other words, our perception plays a role in the way we interpret and frame an issue. Maddison (2007) went further by suggesting that perception and adaptation strategies are the two key components of the adaptation process. As such, any misleading perceptions can cause inappropriate adjustment measures (Taylor et al. 1988) since the way an entity perceives a problem is likely to determine the policies and programmes that they support to address it (Niles et al. 2013). This line of thought, underlying many scientific models, such as 'drivers-pressure-state-impact-response' (DPSIR) (Smeets and Weterings 1999) and source-pathway-receptor (SPR) (Narayan et al. 2012) that focus on identifying causes, is central to developing strategies that tackle environmental problems. Thus, for most actors, their understanding of cause will influence the approach selected. Giving this implication, understanding how stakeholders perceive causes of flooding either as human or climate related (or both) and understanding the different policy strategies is important. Not only is there a weak evidence base on causes of recent flooding in Nigeria, there is little critical enquiry into what perceived causes of flooding mean for the strategies and practices championed by various actors involved in urban flood management.

\section{Adaptation strategies towards flood hazard}

Adapting to climate hazards, such as flooding, has become a key subject of global discussions in the past few years (Wiering et al. 2017; Wilby and Keenan 2012). Adaptation in the context of flood management is viewed as a means of strengthening the resilience of people and places by decreasing their vulnerability to flooding (Wilby and Keenan 2012). Flood adaptation strategies recognise that whilst flood situations cannot be entirely prevented, steps can be taken to prevent or minimise injury and loss and speed the recovery process. As such, adaptation strategies are those that promote anticipatory actions to reduce the expected damage from imminent flooding. This will include practices such as the 'living with water' or 'accommodating water' approach (Fleming 
2002; Wiering and Arts 2006), which rather than fighting flood water and keeping it away or building big infrastructure to stop the water, suggests embracing as opposed to battling the water. Carmin et al. (2015) categorised adaptation options that may need to be considered into structural, institutional and societal measures (institutional and societal measures are non-structural). Structural measures rely on engineered, technological and ecosystem-based investments to reduce vulnerability. Institutional measures draw on laws, regulations, government policies, programmes and services, and economic incentives and mechanisms to encourage or mandate adaptation. Societal strategies use education, awareness, networks and human-capital building to promote changes to individual or community behaviour that enhance resilience. Flood adaptation strategies have become a particularly important and viable option for developing countries as recent flooding have caused widespread destruction and human tragedy (Nyong et al. 2007; Surminski and Oramas-Dorta 2014).

\section{Methodology}

\section{Framing and content analysis}

There are broadly four approaches to content analysis of news media articles, namely semiotic, discourse, narrative and frame analysis (Devereux 2013). In its broadest sense, semiotic analysis is concerned with everything that can be taken as a sign (Eco 1976), which is most relevant to media in the audiovisual form, which is outside the scope of this study that focuses on texts. Discourse analysis, which holds that interests and institutional constraints are the key determinants of policy formulation and implementation, is based on the premise that language is not neutral and should be recognised as a medium through which actors do not simply describe but also create the world (Hajer 1993). As such, the focus of discourse analysis extends beyond differences of opinion expressed in language and includes extra-discursive practices (Müller 2008), such as context and structure of language, from which social constructs emerge. Newspaper articles would not yield this full breadth of data needed; therefore, discourse analysis was not undertaken in this study. Narrative analysis on the other hand focuses on the way individuals present their accounts of themselves, and views self-narrations both as constructions and claims of identity (Linde 1993). The power of narratives in shaping public policy is supported in a variety of academic literature, and the Narrative Policy Framework (NPF) (Jones and McBeth 2010) provides an approach to studying them in a systematic, empirical manner. There is a suggestion by McBeth et al. (2014) that in any policy environment, narratives are as important to policy success as the actions that are taken. Narratives are also the medium through which actors try to impose their view of reality on others, suggest certain social positions and practices, and criticise alternative social arrangements (Jones and McBeth 2010). The crux of the argument is that construction of a particular narrative is an expression of how actors define problems and solutions, and the adoption of a particular narrative could be a means to facilitate mutual learning, build compromises or even undermine policy implications of competing narratives.

In the broader literature, the terms 'narrative' and 'discourse' are often vague and used interchangeably. Thus, similar to discourse analysis, conducting narrative analysis requires a full account of what transpired and not partial statements. Frame analysis is principally concerned with explaining how an issue is defined (why an issue matters) and problematised (who or what might be responsible for a problem), and the effect (what should be done) that this has on the broader discussion of the issue (Hope 2010; Nisbet 2009). According to Entman (1993, p. 52), "to frame is to select some aspects of a perceived reality and make them more salient in a communicating text, in such a way as to promote a particular problem definition, causal interpretation, moral evaluation, and/or treatment recommendation for the item described". In this manner, frames offer both a diagnosis and a prescription to a complex problem or event (Nisbet 2009). Frames highlight bits of information that are embedded within and make themselves manifest in a text - such as a news report (Entman 1993) and as such does not require the extra-discursive practices needed for a discourse analysis or detailed account needed for a narrative analysis. Thus, frame analysis offers an opportunity to analyse part of an account and as such is most relevant to this study. According to Chong and Druckman (2007, p. 100), "frame reveals what the speaker sees as relevant to the topic at hand". By framing issues in specific ways, an entity can declare the underlying causes and likely consequences of a problem and establish criteria for evaluating potential remedies for the problem (Nelson et al. 1997). As a platform for a study that does not include full transcripts/ narratives of actors, frame analysis becomes helpful in identifying and specifying actors' frames around an issue through which their narrative can be constructed.

It is suggested that frames simplify the discursive space and are the medium through which an actor construct their narratives. According to Müller (2017, p. 55), "frames form narratives". The crux of the argument is that actors' narratives often hinge on the construction of their frames. In this study, frame analysis was conducted as a perspective from which we examine how actors represent their perception of flooding in the news media and can give a preliminary insight in narratives of actors. Therefore, this paper adopts the principle that frames illuminate narratives (Crow and Lawlor 2016). Although full narrative analysis or applying the NPF was not possible in this study, we are able to make inferences of actors' narratives on the basis of their frames. 
In this paper, we focus both on actors' texts of the causal factors of flooding and on their suggested solutions as expressed within newspaper reports. Firstly, we identified relevant news articles within the Nigerian news media in which actors reveal their perceptions around key flood debates. Secondly, we examined and categorised these texts into predetermined frames. The causal frames-'human causes' and 'climate-related causes' - are based on the idea that flood can be caused by anthropogenic and natural factors. The adaptation strategy frames are based on the categorising by Carmin et al. (2015) — structural, institutional and societal frames. Finally, since the role perceived causation of floods and other extremes of climate plays in policy strategies has yet to be thoroughly scrutinised (Bohensky and Leitch 2014), we explored if there is any link between how actors frame causes and response or strategies around which actors frame their narratives.

\section{Data collection}

This paper focuses on the frames of state (government) and four non-state actors (corporate, local communities, nongovernmental organisations (NGOs) and multilateral organisations). Broadly speaking, there are three main types of news media. These include print media (newspapers, news magazines), broadcast news (radio and television) and, more recently, the Internet (online newspapers, news blogs, etc.). The findings are based on analyses of articles published in local and national Nigerian newspapers (online versions) between January 2012 and September 2016. January 2012 was selected as a starting date because it reflects the start of greater interest in flooding subsequent to the 2012 major flood event. These sources were collected through comprehensive and extensive searching using databases such as ProQuest and Internetbased search engines (i.e. Google) and searching the websites of major national newspapers (mainly Thisday, The Nation, Vanguard, Guardian and Punch). A structured search employing Boolean searches was conducted using a wide range of terms related to urban flooding in Nigeria. These related to the geography of interest (e.g. urban centres, including specific state names and their capitals/urban centre by name) and infrastructural components of interest (roads, bridges, schools, etc.). An example of string and terms searched include flood* and (urban* or city or state*) and (infrastructure* or resident* or home*) and YR (2012-2016). Most of the newspapers do not have online archives dating back to 2012, so these were supplemented by direct search using the Google search engine.

Identified articles were then subjected to quick review to assess them for duplicates and relevance to the research questions (e.g. geographic coverage, reporting narratives of actors rather than journalist opinion, etc). As our interest is on the framing by main direct policy actors, we have excluded articles such as editorials that report framing by the media outlets. To ensure that we do not dwell on articles whereby news organisation reframes the narratives of key actors, we focus mainly on where direct quotes have been reported as a way to differentiate between media framing and the framing of the actors we have analysed. Whilst duplicates were included in the number of articles for each newspaper, only one was included in the final analysis to avoid double counting. For instance, if two newspapers provide similar report on an incident, then the report from only one of these sources is counted towards the final analysis.

\section{Data analysis}

A quantitative content analysis was applied to code frames deductively (Matthes 2009). Sources were investigated and information collated with particular reference to narratives, activities and actions of stakeholders during the reported flood incidents. The narratives are structured according to the following questions. First, how are the causes of flooding explained by the actor(s) within the news article? Second, what solutions are being promoted by the actor(s) within the news article? The strategies were categorised according to Carmin et al. (2015), who designated pathways for adapting to climate change impacts into structural (such as engineered, technological and ecosystem-based), institutional (such as laws and regulations, government policies, programmes and services) and societal (such as educational, informational, behavioural and social services). Where possible, the strategies were further interrogated as to whether they are reactive/ passive or proactive/anticipatory. Each article was analysed based on this understanding, and following quantitative content analysis, the number of instances of each frame being identified within an article was counted. We then used the overall number of instances where each actor group used a particular framing to arrive at what we conclude as the dominant frame for each actor group. It is therefore possible to extract more than one frame per article (discourse unit) (Matthes 2009). For instance, the unit was the article but several frames could be coded and for more than one actor in each unit. Frames are counted per article and not number of actors within each article. Therefore, for example, there could be two officials in a news article emphasising the same frame and this would count only as one.

Analysis was extended beyond this main focus of the paper to also compile comprehensive data on incidence and impacts of flooding in Nigerian cities, since this could easily be collated from the news articles sourced in the study. Although Bashir et al. (2012) provide a list of flood incidents and associated impacts in selected cities covering up till 2010, 
on the basis of this work, Appendix 1 extends this to September 2016.

\section{Results}

A total of 1704 articles containing the search criteria were generated for the period under study. A review of these to assess for relevance reduced the number of articles to 462 , of which we found that about $68 \%$ were duplicates, often repeating the same statements and in some cases verbatim reports. In the end, 147 articles were analysed. The Nation published 100, Guardian 88, others (such as Premium Times, The Tide, Tribune, etc.) 89, Thisday 51, Vanguard 76 and Punch 58. Of these, we identified 106 articles to analyse frames of government, 68 for local communities, 15 for multilateral organisations, 24 for NGOs and 7 for corporate (private businesses) (Fig. 1). Figure 1 also shows that since the 2012 flood, there was a steady increase in the number of relevant articles, but there was a decline in 2014. Trends in monthly coverage (Fig. 2) show consistency with annual frequency of rainfall with the wet season months of July to September having the highest number of articles.

The next section draws upon frames of actors who have commented on urban flooding in Nigeria from 2012 to September 2016, their perceived causes of flooding (human and climate related) and practiced or proposed solutions to the problem (institutional, structural or societal). The range of frames around flooding in Nigerian cities was identified and compared among various actor groups. Within each dominant frame, the number of times they were identified in all articles analysed for each actor group was computed. The frames are further described below and sample texts/ quotes showing them are presented as supplementary material.

\section{Government}

Governmental actors' narratives portray the challenges of flooding in Nigerian urban centres as mainly human induced (Table 1). Of the 106 articles analysed for government framing, there were 95 frames on possible causes of flooding in cities. Often, multiple causes are indicated within one article. The perceived cause of flooding was put down mainly to 'disregard for laws and regulations' such as 'urban and regional planning laws', 'indiscriminate dumping of refuse, which often blocked drains and other water channels' and 'construction on drainage lines', which was identified in 48 frames (Table 1). Deliberate opening of dams (17 frames) and poor design or construction of infrastructure such as drainage ( 8 frames) were the other two main frames evident within the urban flooding discourse of governmental actors in Nigeria. In 22 frames, reference was made to suggest possible climaterelated factors causing flooding. This was commonly put down to 'unexplained increase or high rainfall' (13 frames) and 'rise in water levels' (especially articles reporting on coastal cities and those along the Niger-Benue River). There were four frames where governmental actors directly mentioned climate change as a causal factor of urban flooding.

The strategies currently practiced or suggested as solutions by governmental actors mainly target structural (102 frames) and institutional (106 frames) approaches (Table 2). There are 77 frames identified for societal approaches within government narratives. Not surprisingly, considering the main perceived cause, the "enforcement of the provisions of environmental and planning laws' through policing and 'demolition of buildings' is highly regarded by governmental actors. However, an unexpected finding is the dominance of engineered approach, e.g. through construction of dams since lack of or poor infrastructure was not that prominent a perceived cause. There is a near absence of ecosystem-based and behavioural approaches in the strategies suggested by governmental actors. The frame of some governmental actors contains some reference to the idea that people have formed
Fig. 1 Summary of articles analysed by newspaper

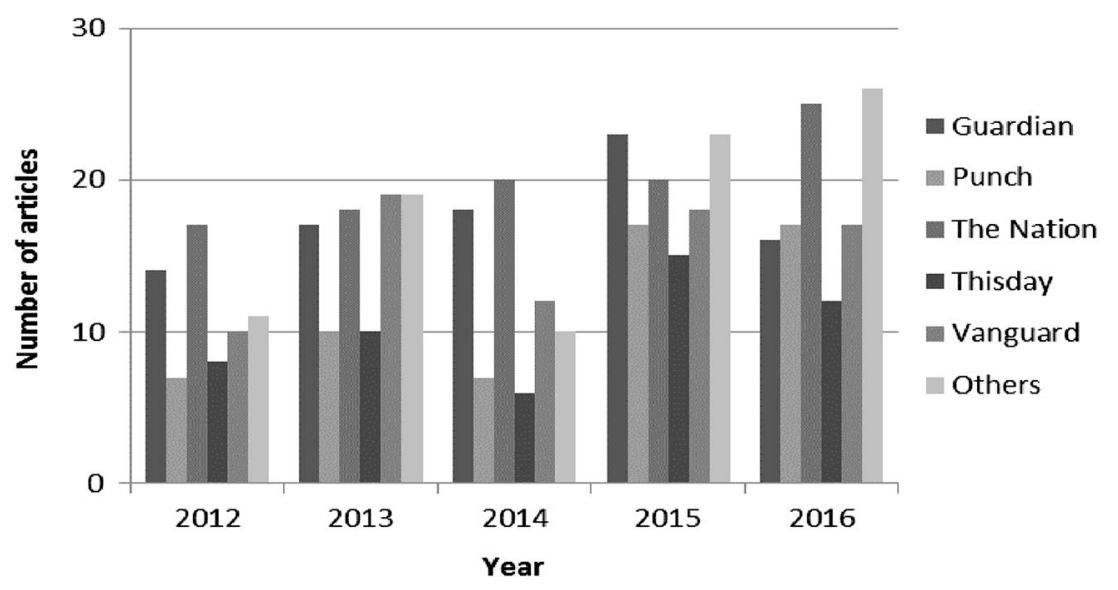


Fig. 2 Summary of articles analysed by month

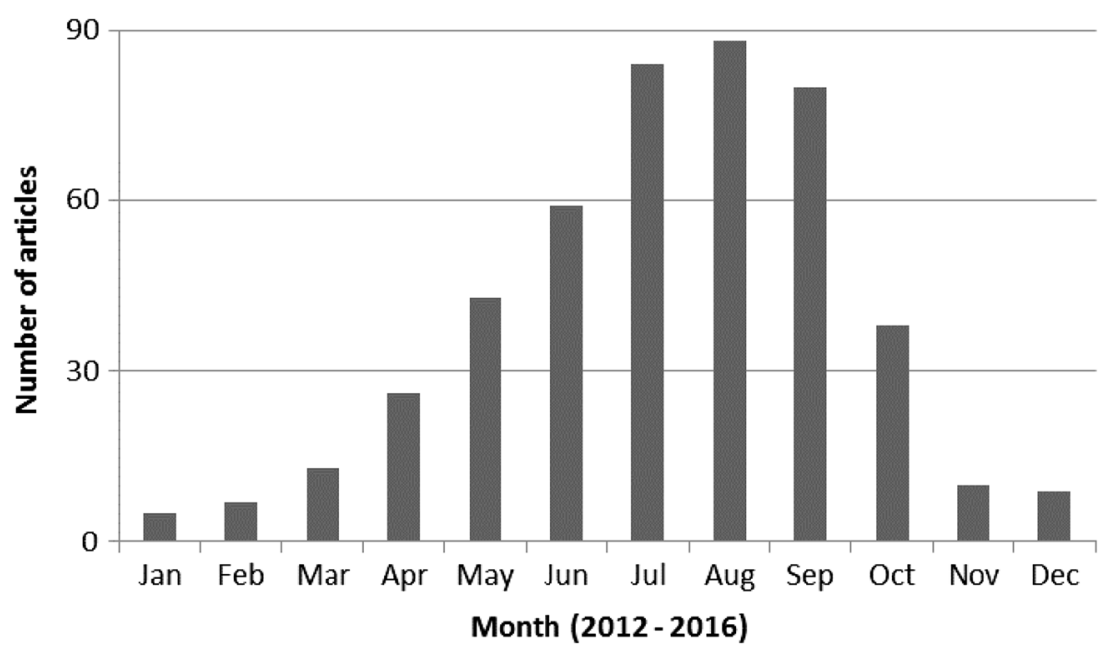

negative habits that may be hard to change. For example, in the view of the Sole Administrator of Apapa in Lagos:

"It will be unfair to spend money which could have been used in the provision of other basic amenities in the state .... on unethical environmental habits" (Olowoopejo 2016).

It is noteworthy that both dominant strategies (structural, institutional) such as enforcing laws and building dams can be anticipatory, but also can reflect a flood control mindset that does not emphasise preparedness for inevitable events and does require significant investment. The majority of the government frames and actions are post flood and largely reactive to a flood incident. For example, the Executive Secretary of Plateau State Emergency Management Agency, PSEMA, stated: "Government heard of the reported cases of flooding in these council areas and we are here to assess the level of damage with a view to mitigating the sufferings of the people". Although he indicated that "the agency had sent out warning signals" (Premium Times 2015), it was obvious that the agency itself was not prepared for the impending flooding. Their lack of preparedness may be related to lack of funding and the greater readiness of government and agencies to provide post-disaster funding over resources for pre-disaster preparedness. This is evident in the fact that monies released after flooding usually far outweigh any allocation to flood adaptation prior to flooding. For instance, during a more recent flooding incident in 2017, the Federal Government released A1.6 billion (USD 5.5 million) to affected states (Ogunmade 2017). The Secretary to the Abia Government said,

the funds for the immediate intervention in the event of flooding are not readily available... If we are faced with

Table 1 Actor groups and framing of cause(s) of flood

\begin{tabular}{|c|c|c|c|c|c|c|c|c|}
\hline \multirow[t]{3}{*}{ Actor group } & \multicolumn{7}{|l|}{ Frames } & \multirow[t]{3}{*}{ Total } \\
\hline & \multicolumn{4}{|l|}{ Human causes } & \multicolumn{3}{|c|}{ Climate related causes } & \\
\hline & $\begin{array}{l}\text { Disregard for laws } \\
\text { and regulations }\end{array}$ & $\begin{array}{l}\text { Deliberate } \\
\text { opening of } \\
\text { dams }\end{array}$ & $\begin{array}{l}\text { Poor } \\
\text { infrastructure }\end{array}$ & Urbanisation & $\begin{array}{l}\text { Unexplained } \\
\text { high rainfall }\end{array}$ & $\begin{array}{l}\text { Unexplained rise } \\
\text { in water levels }\end{array}$ & $\begin{array}{l}\text { Climate } \\
\text { change }\end{array}$ & \\
\hline Government & $48(50 \%)$ & $17(18 \%)$ & $8(8 \%)$ & $0(0 \%)$ & $13(14 \%)$ & $5(5 \%)$ & $4(5 \%)$ & $95(100 \%)$ \\
\hline Local communities & $34(50 \%)$ & $10(15 \%)$ & $9(12 \%)$ & $0(0 \%$ & $14(20 \%)$ & $0(0 \%)$ & $2(2 \%)$ & $68(100 \%)$ \\
\hline Business & $4(55 \%)$ & $0(0 \%)$ & $2(31 \%)$ & $0(0 \%)$ & $1(14 \%)$ & $0(0 \%)$ & $0(0 \%)$ & $6(100 \%)$ \\
\hline $\begin{array}{l}\text { Multilateral } \\
\text { organisations }\end{array}$ & $1(13 \%)$ & $1(11 \%)$ & $0(0 \%)$ & $2(21 \%)$ & $0(0 \%)$ & $1(13 \%)$ & $4(42 \%)$ & $9(100 \%)$ \\
\hline $\begin{array}{l}\text { Non-governmental } \\
\text { organisations }\end{array}$ & $6(28 \%)$ & $2(11 \%)$ & $1(5 \%)$ & $1(3 \%)$ & $3(13 \%)$ & $1(7 \%)$ & $7(33 \%)$ & $21(100 \%)$ \\
\hline Total & $93(46 \%)$ & $31(16 \%)$ & $19(10 \%)$ & $3(1 \%)$ & $30(15 \%)$ & $7(4 \%)$ & $17(8 \%)$ & $200(100 \%)$ \\
\hline
\end{tabular}

Note: The number of samples is not equal, the intention is not to compare across dimensions to capture coverage of each actor group, but rather the focus is on framings in articles covered by the newspapers 
the magnitude of flooding that requires evacuation of the affected communities, we shall beckon on the Federal Government for its intervention (Vanguard 2016).

The challenge may not only be that most of the actions are post-disaster tending towards reactive but are also often shrouded in corruption and conflict (Akioye 2013).

In most of the more recent accounts, especially in 2016, there are indications within the government frames suggesting that the idea of preparing for flooding is gaining ground. For example, in 2016, the government of Anambra proactively set up 28 internally displaced people (IDP) camps in readiness for flooding (Agency Reporter 2016). Likewise, the General Manager of LASEMA, said: "NIMET has informed us that there will be heavier rainfall in Lagos State this year but we are well prepared. We have changed the way we are now doing our roads" (Vanguard 2013). However, whilst governments seem to be coming to terms with the inevitability of flooding in cities, the notion of 'community resilience' beyond being prepared with immediate post-disaster relief is entirely absent.

\section{Local community narratives}

The local communities' narrative mirrors that of governmental actors. Like the government frame, the dominant frame among local actors on the perceived cause of flooding is disregard for laws and regulations (Table 1). This is followed by unexplained rainfall (excessive, unexpected and more than normal), opening of dams and poorly constructed infrastructure. Thus, the framing of causal factors of urban flooding among local community actors is dominantly around anthropocentric factors. Whilst a high proportion of causal frames (21\%) referred to high or unexplained rainfall, which is an indication of climate-related causes, on only two frames do actors directly link causal factors to climate change.

The local narratives exhibited a somewhat even spread on strategies and solutions: structural (43 frames), institutional (47 frames) and societal (41 frames). The dominance of engineered and law and regulation was evident within the local communities' narratives, although in this case engineered was more dominant than laws and regulations. Frames championing the adoption of post-flood social service as a strategy were high among local communities. However, frames suggesting the adoption of behavioural measures are low among local actors. This is a similar trend to the perception of governmental actors.

\section{Corporate actors' narratives}

The articles available to analyse corporate actors' frames were considerably less than those for other actor groups. However, our analysis did show that the narratives of business actors 
focus on disregard for laws and regulations and poor and inadequate infrastructure as the major causes of flooding in Nigerian cities. There was also one frame referring to heavy rainfall (climate-related factor) as a cause of flooding (Table 1). Like government and local community actors, there was a high reference to institutional approaches as the solution to the problem. However, unlike the preceding two actor groups that emphasised the need for laws and regulations, corporate actors' narratives are around the need to promote government policies and economic measures such as provision of insurance.

\section{Multilateral actors' narratives}

There was departure from the foregoing narratives and introduction of a new frame under the multilateral organisation actors. The introduction of 'urbanisation' as a major causal factor of urban flooding was identified within two frames. Overall, the multilateral actors' narrative on causal factors was more evenly balanced between human factors and climate-related factors. This evenly balanced outlook was also reflected in multilateral actors' framing of solutions: structural (11), institutional (12) and societal (11). Even when analysed individually, there was a fair balance between all the different pathways, although with need for government policies being the main frame followed by technological and informational pathways, each with five frames.

\section{Non-governmental organisation narrative}

The narrative of NGOs on causal factors of urban flooding in Nigeria, like that of multilateral organisations, was evenly balanced, suggesting a combination of both climate-related and human factors. There were 10 frames referring to human causes and 11 frames referring to climate-related causes. This narrative directly suggests that climate change is a major reason for the recent upsurge in flooding in Nigerian cities. However, this narrative is more balanced than those of government and local communities due to also including aspects of human causes. It is only within the NGO framing that we find all the causal factor frames (disregard for laws, deliberate opening of dams, poor design, unexplained rainfall, unexplained rise in water levels, urbanisation and climate change). Societal pathway (27 frames) was the main approach suggested as solution, followed by institutional and structural approaches with 17 and 13 frames, respectively. Government policies and educational and social services were the dominant suggested solutions. These are strategies that align most and give the strongest indication of preparedness for flooding.

Overall, among all actor groups, there were 146 frames referring to human causes and 54 frames referring to climate-related causes of flooding (Table 1). Overwhelmingly, the disregard for laws and regulations is the dominant narrative (93 frames, $46 \%$ ) around which causes of urban flood management in Nigeria are framed. On the other hand, narratives around strategies and solutions are more even with $32 \%$ of overall frames suggesting structural pathways, 38\% suggesting institutional pathways and $30 \%$ suggesting societal pathways (Table 2). However, when analysed based on individual approaches, the overwhelming focus on flood prevention becomes apparent with the majority of frames being on the need for engineered solutions (112 frames, $22 \%$ ) and enforcement of laws and regulations (114 frames, $21 \%)$.

When taken collectively to build the narratives of actors around the causes and solution to urban flood in Nigeria, there are four major strands of narratives. The first which is championed by governmental and corporate actors emphasises the human causes of flooding and then seeks institutional adaptation measures as solutions. The second which is held by the local actors also emphasises the human causes of flooding; however, the solutions championed cut across all three adaptation strategies. Third is the narrative of non-governmental organisations which emphasises both human and natural causes of flooding, but is strong on adopting societal adaptation measures as solution. The final narrative held by multilateral actors is most balanced as it emphasises both the human and natural causes of flooding as well as all three adaptation strategies.

\section{Discussion}

The relatively high number of articles to analyse frames of government and local communities is not surprising since they have a direct role and are most visible in flood management. Whilst the decline in number of relevant articles in 2014 might be due to the relatively lower flood incidence that year, the number of articles per month shows consistency with annual frequency of rainfall, with the wet season months of July to September having the highest number of articles. This suggests that publication of flood-related articles in Nigeria media reflects the concept of 'issue-attention cycle' (Downs 1972).

Seven frames categorised as either human (disregard for law and regulations, deliberate opening of dam, poor or inadequate design of drainage infrastructure and urbanisation) or climate-related (unexplained rainfall, unexplained rise in water levels and climate change) causes were identified. Generally, these frames fall into two strands of narratives that can be identified around underlying cause of urban flooding. First is that which dominates among governmental, local community and corporate actors. This emphasises human factors such as disregard for planning laws, poor and blocked drainage systems and indiscriminate dumping of refuse as the main causes of flooding. Although the narrative recognises high intensity of rainfall, not much link is made to climate-related 
variables as a cause of flooding. This does not fully mirror contemporary thinking in flood management that also tends to emphasise climate-related causes of flood, their inevitability, especially considering climate change and consequent changes in extreme events (Hirabayashi et al. 2013). On the other hand, contemporary thinking in flood management is reflected in a second strand of causal factor narratives which dominates among multilateral and NGO actors. This is more balanced and lays equal emphasis on both human and climate-related factors (Schaller et al. 2016), suggesting the inevitability of flood incidents as a central issue in a recent spate of urban flooding in Nigerian cities. However, when considered individually, the details reveal some subtle issues. The first is that in only two frames do local actors directly link causal factors to climate change. This could suggest a low understanding among local actors of what constitutes 'typical' rainfall and climate change and impacts within Nigerian urban centres. The implication of such a perspective is an inevitable shortterm thinking and, particularly as regards infrastructure, a reactive approach. Second, the low number of frames around urbanisation as a causal factor could be worrying considering the high rate of urban growth in Nigeria and understanding such growth from the point of view of natural hazards such as flooding (Douglas et al. 2008). The absence of such within the framing of government and local actors especially could imply this is not being considered within policy development.

Logically, considering the overwhelming framing of the causal factor of disregard for laws and regulations, one would expect an equal emphasis on a laws and regulations approach as the preferred solution. However, although this featured heavily, it was not the highest strategy perceived as required to manage flooding. An engineered approach was more frequently mentioned. Although there was a framing around inadequate infrastructure as cause of flooding (19 frames, 10\%), this does not explain the high number of frames suggesting engineered solutions to the problem. This suggests that the nature of perceived causal factors of flooding, whilst an important determinant of strategies that actors will suggest be adopted in flood management, is not the only influence at play. Preference for structural engineering approaches is in line with a general preference for technocratic approaches and abrogation of responsibility for solutions seen universally (Harvatt et al. 2011).

The strategies frames of local community and multilateral actors are more evenly spread across the three broad solution frames. Whereas governmental and business actors frame suggested solutions more around institutional strategies, nongovernmental organisations' frames are more towards societal strategies. When considered individually across specific themes under each frame, there is a dominance of focus on the need for government policies as the main approach among business, multilateral and non-governmental organisations. This is interesting if considered that locals and government who are direct actors favour different approaches, i.e. engineered among locals and laws and regulations among government actors. The implication of such differences as a potential arena of conflicts is discussed below. Further insights from the results show that main policy actors champion the adoption of structural and non-structural strategies to combat flood hazards and there is no preponderance of one over the other in the narratives of all five groups. This aligns with the observation of Adelekan and Asiyanbi (2016), that there has been a shift in balance from structural to non-structural approaches in flood risk management in Lagos-Nigeria's most populous city, and further underscores the need to rethink the idea that developing countries are reliant on structural measures to control floods.

The dominance of engineered over laws and regulations evident within the local communities' narratives makes for the interesting interpretation that local actors may be assuming that with a better engineered approach, their behavioural disregard of law can be excused. Likewise, the dominance of engineered approach among government actors was unexpected since lack of or poor infrastructure was not that prominent a perceived cause. The implication is that whilst government perceives the people as the main cause of flooding, they believe flooding can best be solved by engineered changes and building more infrastructure rather than addressing behaviours directly. The control mindset is also evident in the fact that behavioural measures is one of the least mentioned (only higher than ecosystem-based approach) and resonates with an authoritative view that people have already developed negative environmental habits and will probably not behave correctly. This is noteworthy and may be an indication that both governmental and local actors either undervalue or perceive difficulty in getting people to act or to change their behaviour to meet flood management outcomes. This poses a challenge for contemporary flood management, which places emphasis on behavioural measures (Fazey et al. 2016) and the role of citizens in taking some responsibility for flood risk management (Butler and Pidgeon 2011; Terpstra and Gutteling 2008). Ensuring that communities engage in behavioural approaches is especially important because connected with the adaptation narrative is the standpoint that flood risk cannot be either avoided or eradicated, and citizens should accept more personal responsibility. However, as pointed out by White et al. (2010), if we expect people to accept more responsibility and possibly adopt behavioural approaches, then they should be involved in decisions connected with flooding. This probably could be a pointer to the need for Nigerian cities to place considerable emphasis on public consultation and engagement in urban flood management. The near absence of an ecosystem-based approach within governmental narratives may be connected to the fact that government has been blamed as complicit in degradation of ecosystems (Adekola et al. 2012). 
Frames championing the adoption of post-flood social service as a strategy were high among local communities and there is evidence that governments already provide this through emergency agencies with support from nongovernmental and multilateral organisations. However, this is often mostly shrouded in corruption (Gwaza 2014). This is an area government will need to address if flood adaptation is to be successful and sustainable. Whilst an informational approach was also regarded within the local actors' narrative, evidence suggests that government and practitioners may need to do more than just providing locals with information as some may be complacent. For example, a resident of Kogi State said, "I am not bothered about the report of the impending flood,... Nigerian Meteorological Agency made similar predictions in the past and nothing happened. No serious flood can come now; it should be after many years. I am not moved at all by this warning and I will not leave this place" (Abutu et al. 2015). In another instance, a local indicated he is ready to die rather than respond to the warning by emergency agency: "I have been living all my life here where do I go from here and what do I fall back on to fend for my family? I can't leave here even if death is knocking at my door" (Mosadomi 2016). Whilst these views may be due to cultural and economic constraints, they illustrate the importance of targeting appropriate provision of information and communicating inherent uncertainties, as well as backing up information provision with preparedness education and awareness.

The prevailing urban flood management practices in Nigerian urban centres are mostly reactive responding to prevailing disaster situations (emergency response and recovery) rather than being proactive. This is in line with the findings of recent studies on flood management in Nigerian cities (Agbonkhese et al. 2014; Nkwunonwo et al. 2016). This is not surprising as it aligns with governments' narrative that flood can be prevented; hence, action must be taken to prevent any further incidence. Prioritising anticipatory actions will require a refocusing on flood management policies (Olorunfemi 2011). This will entail a policy shift that may also depend upon changes or realignment in existing laws and regulations to make them fit for purpose (i.e. collaborative design of policy). It has been suggested that various environmental laws and regulations in Nigeria fail mainly because they are top-down and have no recourse to citizen participation (Etemire 2015; Olowoporoku 2016). Furthermore, evidence suggests that where local communities in Nigeria are engaged in policy-making, there is high success and compliance with accompanying regulations (Olaseha et al. 2005). Any new policy should therefore include a review of existing laws and regulations in consultation with stakeholders, including local communities in order to enhance compliance to those regulations. In this context, having a 'Nigerian policy on flooding' could provide a key to changing reactive response to proactive responses that increases effectiveness of management and reduce losses of life and properties. A similar approach, adjudged as successful, has been adopted in South Africa (Viljoen et al. 2001) and Ireland (The Office of Public Works 2004).

Our finding shows disparities in the narratives of actors which could be potential for conflict in flood management. For instance, the dominance of the need for government policies within multilateral organisations' narratives could lead to practices among such organisations operating in Nigeria, whereby they will offer governments 'financial aid conditionalities' for them to adopt policies (mostly based on western ideologies) in return for bilateral and multilateral donor grants. However, as evident from above (narratives of government and local communities), local actors may not see these as key priorities. This may then lead to situations whereby it has been observed that governments collect the funds and claim to invest in policies but yet the problem still persists (Agrawal 2007). There is a need in such circumstances for 'outside' actors to engage government and local actors and understand perceptions and priorities and realise that there could be more than one plausible interpretation of reality (Tamboukou et al. 2013). For instance, whilst urban centres in developed countries where the multilateral, nongovernment and business interests originate from may have systems and institutions that ensure stricter adherence to laws and regulations, many developing countries struggle more with this and compliance may be the starting point for most discourse on urban flood management. This subtle disparity between direct actors and those with funding or mediating roles calls for caution, especially when it comes to building consensus and evolving strategies on flood management in developing regions.

The framing of solution to flooding as laws and order and engineering solutions among direct actors (government and local communities) re-echo approaches such as 'flood control' (Butler and Pidgeon 2011) and 'through police power' (Dunham 1959), which were dominant in developed countries in the last century. Contemporary thinking within these societies has now moved beyond this to more focus on flood adaptation that recognises the inevitability of flooding. This could also be an arena of lack of policy consensus between local actors and foreign actors and could present difficulties when developed societies try to assist developing societies such as Nigeria in flood management. Thus, understanding of flooding issues should be context-based and incorporate appreciation of how local actors perceive underlying issues, rather than from representations that may not necessarily reflect local realities. This is the way forward if we are to ensure that adaptation policy (Nyong et al. 2007) does not result in conflicts (Swart and Raes 2007) that will undermine flood management.

That said, the implication is by no means one-directional as local actors' frames are a departure from now global best 
practices that emphasise adaptation to flood (United Nations Office for Disaster Risk Reduction 2015) and promote societal approaches that prepare for flooding when it occurs. Government may continue to spend significantly on flood defences that do not prevent flooding, and when the latter occurs, there are consequently not enough funds to manage the aftermath. There is a need for reorientation and engagement of all actors and an understanding of the limits of engineered approaches (Johnson et al. 2005; Mitchell 2003). This should also include promoting the benefits of mainstreaming resilience beyond the management of disaster that underlies the new approaches (Friend et al. 2014). This engagement should start with understanding the factors underlying causes of flooding in Nigerian cities and probably comprehension of uncertainties surrounding causes of flooding. Other authors have found that media narratives are often dominated by reference to the uncertainties around the causes of flooding (Beckert 2010; Bohensky and Leitch 2014).

Whilst there were disparities in the framing and narratives, the narratives of governmental and corporate actors were highly consistent. Whilst this was unexpected, it could suggest opportunity to involve corporate actors to play more vital role in urban flood management in Nigeria. Results also showed that actors having similar frames of causes did not necessarily suggest similar solutions. This implies that the framing of causes is not the only factor that influences actors' suggested solutions.

For the period studied, news media have not covered some actors, especially the business and multilateral organisations' narratives with the same attention given to other actors. Of course, this is not one-dimensional; however, multinationals and NGOs looking to affect policy could consider whether improved coverage in Nigerian media could advance their purpose. For instance, for NGOs and multinational organisations advocating education as a route to behaviour change and a societal approach, higher visibility of these frames in the media has the potential to influence public perception and thereby policy (Miles and Morse 2007).

\section{Conclusion}

This study analysed newspaper articles to understand how actors (government, local community, corporate, multilateral and NGOs) have framed perceived underlying causes and solutions to urban flooding in Nigeria. In the analysis of the results, two dominant narratives, discourse around enforcement of laws and regulations and an engineered approach, can be identified as presiding in the framing of urban flooding in Nigeria. Each of these narratives has different discursive underpinnings around which they frame the 'problem' of urban flooding and its 'solutions'. The narratives of government, local communities and businesses align with the premise that flooding can and should be prevented whilst that of multilateral and business actors champion adaptation strategies on the basis that flooding is inevitable and, hence, more energy should be directed at 'living with water'-emergency response, damage reduction and the aftermath. The study also identified areas of potential consensus and conflict between direct actors such as government and local communities on the one hand and funders on the other. Better discussion aiding understanding of contemporary thinking and local realities will aid policy-making and policy implementation in the Nigerian context, perhaps through the design of a 'Nigerian policy on flooding' which currently does not exist.

This study makes an important contribution to literature on how analysis of media articles in a developing country context could enhance understanding of contemporary environmental challenges. Furthermore, our study helps to make transparent the positions of various actors on the issue of urban flooding in Nigeria. A wider analysis of media narratives covering other types of news media, grey literature, local, national and international, could yield better understanding of the frames of actors such as multinationals that are not well captured within the local and national Nigerian news media. That said, we do suggest NGOs, multilateral organisations and business to consider the advantages of engaging with Nigerian newspapers, especially now that they are online and reach a wider audience. It would be interesting to compare these public narratives of incidences with predicted and actual meteorological data provided by the Nigerian Meteorological Agency (NIMET), but this is beyond the scope of the current study.

Acknowledgements We are grateful to Nevil Quinn for giving his time and providing useful insights and comments to our manuscript.

Funding information The study was conducted as a contribution to the Urbanisation Research Nigeria (URN) programme which had funding from the Department for International Development (DFID) in the UK.

Open Access This article is distributed under the terms of the Creative Commons Attribution 4.0 International License (http:// creativecommons.org/licenses/by/4.0/), which permits unrestricted use, distribution, and reproduction in any medium, provided you give appropriate credit to the original author(s) and the source, provide a link to the Creative Commons license, and indicate if changes were made.

\section{References}

Abiodun BJ, Salami AT, Tadross M (2011) Climate change scenarios for Nigeria: understanding biophysical impacts. Climate Systems Analysis Group, Cape Town, for building Nigeria's response to climate change Project.Ibadan, Nigeria. Nigerian Environmental Study/Action Team (NEST), Ibadan

Abutu A, Abah H, Alabi CT, Sule ID (2015) Panic across Nigeria as flood threaten. Daily Trust, 15 August [Online]. Available at http://www. dailytrust.com.ng/news/news/panic-accross-nigeria-as-flood- 
threaten/106485.html\#Q3Qy18Zwd90uHkEK.99. Accessed 14 Jan 2017

Adekola O, Whanda S, Ogwu F (2012) Assessment of policies and legislation that affect management of wetlands in Nigeria. Wetlands 32(4):665-677. https://doi.org/10.1007/s13157-012-0299-3

Adelekan IO (2010) Vulnerability of poor urban coastal communities to flooding in Lagos, Nigeria. Environ Urban 22(2):433-450. https:// doi.org/10.1177/0956247810380141

Adelekan IO, Asiyanbi AP (2016) Flood risk perception in flood-affected communities in Lagos, Nigeria. Nat Hazards 80(1):445-469. https:// doi.org/10.1007/s11069-015-1977-2

Adeyemi O, Adenusi Rotimi D, Osunsanmi Temidayo OB (2015) State of infrastructure procurement in Lagos State, Nigeria: the PPP approach. Glob J Manag Bus Res 15:7-17. 10.17406/GJMBR

Agbonkhese O, Agbonkhese EG, Aka EO, Joe-Abaya J, Ocholi M, Adekunle A (2014) Flood menace in Nigeria: impacts, remedial and management strategies. Civ Environ Res 6:32-40. www.iiste. org/Journals/index.php/CER/article/view/12140

Agency Reporter (2016) Obiano sets up 28 IDPs in readiness for flooding. The Nation, 15 September [Online]. Available at http:// thenationonlineng.net/obiano-sets-28-idps-readiness-flooding/. Accessed 13 Jan 2017

Agrawal A (2007) Forests, governance, and sustainability: common property theory and its contributions. Int J Commons 1(1):111-136. 10. 18352/ijc. 10

Ajibade I, McBean G, Bezner-Kerr R (2013) Urban flooding in Lagos, Nigeria: patterns of vulnerability and resilience among women. Glob Environ Chang 23(6):1714-1725. https://doi.org/10.1016/j. gloenvcha.2013.08.009

Akioye S (2013) Money, money everywhere, yet flood pains remain. The Nation 26 August [online]. Available at http://thenationonlineng.net/ money-money-everywhere-yet-flood-pains-remain/. Accessed 14 Jan 2017

Akpan C, Anorue L, Ukonu M (2012) An analysis of the influence of the Nigerian mass media on public understanding of climate change. $\mathrm{J}$ Altern Perspect Soc Sci 4:688-710. http://www.unn.edu.ng/ publications/files/12041_An_Analysis_of the_Influence_of the Nigerian_Mass_Media_on_Public_Understanding_of_Climate_ Change.pdf

Babanyara YY, Usman HA, Saleh UF (2010) An overview of urban poverty and environmental problems in Nigeria. J Human Ecol 31: 135-143 SSRN: https://ssrn.com/abstract=1876748

Bashir OO, Oludare AH, Johnson OO, Aloysius B (2012) Floods of fury in Nigerian cities. J Sustain Dev 5(7):69-79. https://doi.org/10. 5539/jsd.v5n7p69

Beckert J (2010) How do fields change? The interrelations of institutions, networks, and cognition in the dynamics of markets. Organ Stud 31(5):605-627. https://doi.org/10.1177/0170840610372184

Bohensky EL, Leitch AM (2014) Framing the flood: a media analysis of themes of resilience in the 2011 Brisbane flood. Reg Environ Chang 14(2):475-488. https://doi.org/10.1007/s10113-013-0438-2

Butler C, Pidgeon N (2011) From 'flood defence' to 'flood risk management': exploring governance, responsibility, and blame. Environ Plann C: Gov Policy 29(3):533-547. https://doi.org/10.1068/ c09181j

Carmin J, Tierney K, Chu E, Hunter L, Roberts T, Shi L (2015) Adaptation to climate change. In: Dunlap RE, Brulle R (eds) Sociological perspectives on climate change. Oxford University Press, Oxford. https://doi.org/10.1093/acprof:oso/9780199356102. 003.0006

Chong D, Druckman JN (2007) A theory of framing and opinion formation in competitive elite environments. J Commun 57(1):99-118. https://doi.org/10.1111/j.1460-2466.2006.00331.x

Crow DA, Lawlor A (2016) Media in the policy process: using framing and narratives to understand policy influences. Rev Policy Res 33(5):472-491. https://doi.org/10.1111/ropr.12187/full
Devereux E (2013) Understanding the media, 3rd edn. Sage, London

Devitt C, O'Neill E (2017) The framing of two major flood episodes in the Irish print news media: implications for societal adaptation to living with flood risk. Public Uderstanding Sci 26(7):872-888. https://doi.org/10.1177/0963662516636041

Di Baldassarre G, Montanari A, Lins H, Koutsoyiannis D, Brandimarte L, Blöschl G (2010) Flood fatalities in Africa: from diagnosis to mitigation. Geophys Res Lett 37(22):1-5. https://doi.org/10.1029/ 2010GL045467

Douglas I, Alam K, Maghenda M, McDonnell Y, McLean L, Campbell J (2008) Unjust waters: climate change, flooding and the urban poor in Africa. Environ Urban 20(1):187-205. https://doi.org/10.1177/ 0956247808089156

Doulton H, Brown K (2009) Ten years to prevent catastrophe?: discourses of climate change and international development in the UK press. Glob Environ Chang 19(2):191-202. https://doi.org/10. 1016/j.gloenvcha.2008.10.004

Downs A (1972) Up and down with ecology: the "issue-attention cycle". In: David P, Maxwell EM (eds) Agenda setting: readings on media, public opinion, and policymaking. Routledge, London, pp 27-34

Dunham A (1959) Flood control via the police power. Univ Pa Law Rev 107(8):1098-1132. https://doi.org/10.2307/3310483

Eco U (1976) A theory of semiotics vol 217. Indiana University Press, Bloomington. https://doi.org/10.1007/978-1-349-15849-2

Entman RM (1993) Framing: toward clarification of a fractured paradigm. J Commun 43(4):51-58. https://doi.org/10.1111/j.14602466.1993.tb01304.x

Eriksen S, Aldunce P, Bahinipati CS, Martins RDA, Molefe JI, Nhemachena C, O'Brien K, Olorunfemi F, Park J, Sygna L, Ulsrud K (2011) When not every response to climate change is a good one: identifying principles for sustainable adaptation. Clim Dev 3(1):7-20. https://doi.org/10.3763/cdev.2010.0060

Escobar MP, Demeritt D (2014) Flooding and the framing of risk in British broadsheets, 1985-2010. Public Underst Sci 23(4):454471. https://doi.org/10.1177/0963662512457613

Etemire U (2015) Law and practice on public participation in environmental matters: the Nigerian example in transnational comparative perspective. Routledge, New York

Fazey I, Wise RM, Lyon C, Câmpeanu C, Moug P, Davies TE (2016) Past and future adaptation pathways. Clim Dev 8(1):26-44. https://doi. org/10.1080/17565529.2014.989192

Federal Government of Nigeria (2013) Nigeria: post-disaster needs assessment 2012 floods. National Emergency Management Agency; World Bank, Abuja

Fleming G (2002) How can we learn to live with rivers? The findings of the Institution of Civil Engineers Presidential Commission on floodrisk management. Philos Trans Ser A Math Phys Eng Sci 360(1796): 1527-1530. https://doi.org/10.1098/rsta.2002.1014

Ford JD, Berrang-Ford L, Bunce A, McKay C, Irwin M, Pearce T (2015) The status of climate change adaptation in Africa and Asia. Reg Environ Chang 15(5):801-814. https://doi.org/10.1007/s10113014-0648-2

Friend R, Jarvie J, Reed SO, Sutarto R, Thinphanga P, Toan VC (2014) Mainstreaming urban climate resilience into policy and planning; reflections from Asia. Urban Adapt Clim Environ Chang: Gov Policy Plann 7:6-19. https://doi.org/10.1016/j.uclim.2013.08.001

Gwaza PA (2014) Appraising response to the plight of victims of natural disasters in nigeria: challenges and prospects 1-20 https://ssrn.com/ abstract $=2483014$

Haider-Markel DP, Delehanty W, Beverlin M (2007) Media framing and racial attitudes in the aftermath of Katrina. Policy Stud J 35(4):587605. https://doi.org/10.1111/j.1541-0072.2007.00238.x

Hajer M (1993) Discourse coalitions and the institutionalisation of practice: the case of acid rain in Britain. In: Fischer F, Forester J (eds) The argumentative turn in policy analysis and planning. Duke 
University Press, Durham, pp 43-76. https://doi.org/10.1215/ 9780822381815-003

Hansen A (2010) Environment, media and communication. Routledge, Oxon

Harvatt J, Petts J, Chilvers J (2011) Understanding householder responses to natural hazards: flooding and sea-level rise comparisons. J Risk Rese 14(1):63-83. https://doi.org/10.1080/13669877.2010.503935

Hirabayashi Y, Mahendran R, Koirala S, Konoshima L, Yamazaki D, Watanabe S, Kim H, Kanae S (2013) Global flood risk under climate change. Nat Clim Chang 3(9):816-821. https://doi.org/10.1038/ nclimate 1911

Hope M (2010) Frame analysis as a discourse-method: framing 'climate change politics'. In: Proceedings of Post-Graduate Conference on Discourse Analysis, Bristol. https://www.scribd.com/document/ 338564425/Frame-Analysis-as-a-Discourse-Method-FramingClimate-Change-Politics-Mat-Hope

Hutter G, Leibenath M, Mattissek A (2014) Governing through resilience? Exploring flood protection in Dresden, Germany. Soc Sci 3(2):272-287. https://doi.org/10.3390/socsci3020272

International Federation of Red Cross and Red Crescent Societies (2013) Emergency appeal operation update Nigeria: floods vol 2. Available at http://www.ifrc.org/docs/Appeals/12/MDRNG01402.pdf, http:// reliefweb.int/sites/reliefweb.int/files/resources/Nigeria\%20flood.pdf

Jalayer F, De Risi R, Kyessi A, Mbuya E, Yonas N (2015) Vulnerability of built environment to flooding in African cities. In: Stephan P et al. (eds) Urban vulnerability and climate change in Africa. Future city 4 edn. Springer, London, pp 77-106

Jiang L, O’Neill BC (2017) Global urbanization projections for the shared socioeconomic pathways. Glob Environ Chang 42:193-199. https:// doi.org/10.1016/j.gloenvcha.2015.03.008

Johnson CL, Tunstall SM, Penning-Rowsell EC (2005) Floods as catalysts for policy change: historical lessons from England and Wales. Water Resour Dev 21(4):561-575. https://doi.org/10.1080/ 07900620500258133

Jones MD, McBeth MK (2010) A narrative policy framework: clear enough to be wrong? Policy Stud J 38(2):329-353. https://doi.org/ 10.1111/j.1541-0072.2010.00364.x

Kahneman D, Tversky A (1984) Choices, values, and frames. Am Psychol 39:341. https://doi.org/10.1037/0003-066X.39.4.341

Linde C (1993) Life stories: the creation of coherence. Oxford University Press, Oxford

Lwasa S (2010) Adapting urban areas in Africa to climate change: the case of Kampala. Curr Opin Environ Sustain 2:166-171. https://doi. org/10.1016/j.cosust.2010.06.009

Maddison DJ (2007) The perception of and adaptation to climate change in Africa vol paper 4308. World Bank, WA https://doi.org/10.1596/ $1813-9450-4308$

Matthes J (2009) What's in a frame? A content analysis of media framing studies in the world's leading communication journals, 1990-2005. J Mass Commun Q 86:349-367. https://doi.org/10.1177/ 107769900908600206

McBeth MK, Jones MD, Shanahan EA (2014) The narrative policy framework. In: Sabatier PA, Weible C (eds) Theories of the policy process, vol 3. Westview Press, Boulder, 2, pp 225-266. https://doi. org $/ 10.1177 / 107769900908600206$

McNair B (2009) News and journalism in the UK. vol Book, Whole, 5th edn. Routledge, Oxon

Metz HC (1991) Nigeria: a country study. Federal Research Division of the Library of Congress, Washington

Miles B, Morse S (2007) The role of news media in natural disaster risk and recovery. Ecol Econ 63(2-3):365-373. https://doi.org/10.1016/j. ecolecon.2006.08.007

Mitchell JK (2003) European river floods in a changing world. Risk Anal 23:567-574. https://doi.org/10.1111/1539-6924.00337

Mmom PC, Aifesehi PE (2013) Impact of the 2012 flood on water quality and rural livelihood in the Orashi Province of the Niger Delta,
Nigeria. J Geogr Geol 5(3):216-225. https://doi.org/10.5539/jgg. v5n3p216

Mosadomi W (2016) Floods: we are ready to die than leave our farmlands, fishes - defiant villagers. Vanguard 24 September [online]. Available at https://www.vanguardngr.com/2016/09/floods-readydie-leave-farmlands-fishes-defiant-villagers/. Accessed 10 Feb 2017

Mugume SN, Melville-Shreeve P, Gomez D, Butler D (2017) Multifunctional urban flood resilience enhancement strategies. Proc Institution Civ Eng Water Manage 170:115-127. https://doi. org/10.1680/jwama.15.00078

Müller M (2008) Reconsidering the concept of discourse for the field of critical geopolitics: towards discourse as language and practice. Polit Geogr 27(3):322-338. https://doi.org/10.1016/j.polgeo.2007.12.003

Müller M (2017) The world according to Israeli newspapers: representations of international involvement in the Israeli-Palestinian conflict. vol 25, vol Book, Whole. Frank \& Timme GmbH, Berlin

Narayan S, Hanson S, Nicholls RJ, Clarke D, Willems P, Ntegeka V, Monbaliu J (2012) A holistic model for coastal flooding using system diagrams and the source-pathway-receptor (SPR) concept. Nat Hazards Earth Syst Sci 12(5):1431-1439. https://doi.org/10.5194/ nhess-12-1431-201

Nelson TE, Clawson RA, Oxley ZM (1997) Media framing of a civil liberties conflict and its effect on tolerance. Am Polit Sci Rev 91(03):567-583. https://doi.org/10.2307/2952075

Niles MT, Lubell M, Haden VR (2013) Perceptions and responses to climate policy risks among California farmers. Glob Environ Chang 23(6): 1752-1760. https://doi.org/10.1016/j.gloenvcha.2013.08.005

Nisbet MC (2009) Communicating climate change: why frames matter for public engagement. Environ Sci Policy Sustain Dev 51(2):1223. https://doi.org/10.3200/ENVT.51.2.12-23

Nkwunonwo UC, Whitworth M, Baily B (2016) A review and critical analysis of the efforts towards urban flood risk management in the Lagos region of Nigeria. Nat Hazards Earth Syst Sci 16(2):349-369. https://doi.org/10.5194/nhess-16-349-2016

Nyong A, Adesina F, Elasha BO (2007) The value of indigenous knowledge in climate change mitigation and adaptation strategies in the African Sahel. Mitig Adapt Strateg Glob Chang 12(5):787-797. https://doi.org/10.1007/s11027-007-9099-0

Ogu VI (2009) Urban infrastructure development and sustainability in Nigeria. Human Settlement Dev III:109 http://www.eolss.net/ sample-chapters/c14/e1-18-05-05.pdf

Ogunmade O (2017) Osinbajo orders release of N1.6bn relief aid for flood victims in 16 states. Thisday 13 July [online]. Available at https://www.thisdaylive.com/index.php/2017/07/13/osinbajoorders-release-of-n1-6bn-relief-aid-for-flood-victims-in-16-states/. Accessed 2 Aug 2017

Olaseha IO, Sridhar MKC, Oyewo OA (2005) Developing sustainable market waste management through the joint efforts of technocrats and traders: a case study from Ibadan, Nigeria. Int J Health Promot Educ 43(2):36-44. https://doi.org/10.1080/14635240.2005. 10708037

Olorunfemi F (2011) Managing flood disasters under a changing climate: lessons from Nigeria and South Africa. NISER Research Seminar Series, NISER, Ibadan. Vol. 3. Available at http:/humanitarianlibrary. org/sites/default/files/2013/08/OLORUNFEMI NRSS DISCUSSION PAPER I.pdf

Olowoopejo M (2016) Lagos blames residents for persistent flooding. Vanguard 27 June [online]. Available at https://www.vanguardngr. com/2016/06/lagos-blames-residents-persistent-flooding/. Accessed 8 Feb

Olowoporoku O (2016) A recipe for disaster: an assessment of environmental sanitation situation in Nigeria. MAYFEB J Environ Sci 1:15 http://www.mayfeb.com/OJS/index.php/ENV/article/view/149

Orubuloye IO (1995) The demographic situation in Nigeria and prospects for fertility transition. J Int Dev 7(1):135-144. https://doi.org/10. 1002/jid.3380070109 
Oshodi L (2013) Flood management and governance structure in Lagos, Nigeria

Premium Times (2015) Flood: relocate to safe areas, Plateau advises residents. Premium Times 23 August [Online]. Available at https:// www.premiumtimesng.com/regional/north-central/188831-floodrelocate-to-safe-areas-plateau-advises-residents.html. Accessed 3 Feb 2017

Rinne P, Nygren A (2016) From resistance to resilience: media discourses on urban flood governance in Mexico. J Environ Policy Planning 18(1):4-26. https://doi.org/10.1080/1523908X.2015.1021414

Robinson P (2001) Theorizing the influence of media on world politics models of media influence on foreign policy. Eur J Commun 16(4): 523-544. https://doi.org/10.1177/0267323101016004005

Schaller N, Kay AL, Lamb R, Massey NR, Van Oldenborgh GJ, Otto FEL, Sparrow SN, Vautard R, Yiou P, Ashpole I, Bowery A, Crooks SM, Haustein K, Huntingford C, Ingram WJ, Jones RG, Legg T, Miller J, Skeggs J, Wallom D, Weisheimer A, Wilson S, Stott PA, Allen MR (2016) Human influence on climate in the 2014 southern England winter floods and their impacts. Nat Clim Chang 6(6):627634. https://doi.org/10.1038/nclimate2927

Smeets E, Weterings R (1999) Environmental indicators: typology and overview. vol Book, Whole. European Environment Agency, Copenhagen

Steinberg S (2007) An introduction to communication studies. vol Book, Whole. Juta and Company Ltd, Cape Town

Surminski S, Oramas-Dorta D (2014) Flood insurance schemes and climate adaptation in developing countries. J Disaster Risk Reduct 7: 154-164. https://doi.org/10.1016/j.ijdrr.2013.10.005

Swart ROB, Raes F (2007) Making integration of adaptation and mitigation work: mainstreaming into sustainable development policies? Clim Pol 7(4):288-303. https://doi.org/10.1080/14693062.2007. 9685657

Tamboukou M, Andrews M, Squire C (2013) Introduction: what is narrative research? In: Andrews M, Squire C, Tamboukou M (eds) Doing narrative research, 2nd edn. Sage, California

Taylor JG, Stewart TR, Downton M (1988) Perceptions of drought in the Ogallala Aquifer region. Environ Behav 20(2):150-175. https://doi. org/10.1177/0013916588202002

Terpstra T, Gutteling JM (2008) Households' perceived responsibilities in flood risk management in the Netherlands. Int J Water Res Dev 24(4):555-565. https://doi.org/10.1080/07900620801923385

Texier P (2008) Floods in Jakarta: when the extreme reveals daily structural constraints and mismanagement. Disaster Prev Manag 17(3): 358-372. https://doi.org/10.1108/09653560810887284

The Office of Public Works (2004) Report of the flood policy review group. The Office of Public Works, Trim, Co. Meath. Available at http://www.cfram.ie/pdfs-downloads/Flood_Policy_Review_ Group.pdf

The World Bank (2016) Data: Nigeria [Online]. Available at http://data. worldbank.org/country/nigeria. Accessed 13 Mar 2017

Thompson M, Warburton M (1985) Decision making under contradictory certainties: how to save the Himalayas when you can't find out what's wrong with them. J Appl Syst Anal 12:3-34. https:// ostromworkshop.indiana.edu/library/node/43015

Tremearne AJN (1910) Notes on some other British West African peoples. J R Soc Arts 58:839-847 http://www.jstor.org/stable/41339263

Ugonna C (2016) A review of flooding and flood risk reduction in Nigeria. Glob J Human Soc Sci Res 16:23-42 https:// socialscienceresearch.org/index.php/GJHSS/article/view/1717
Ukonu MO, Akpan CS, Anorue LI (2012) Nigerian newspaper coverage of climate change, 2009-2010. New Media Mass Commun 5:2230. http://citeseerx.ist.psu.edu/viewdoc/download?doi=10.1.1.959. $8135 \&$ rep=rep $1 \&$ type $=$ pdf

United Nations Office for Disaster Risk Reduction (2015) Sendai framework for disaster risk reduction 2015-2030. United Nations, Geneva. http://www.preventionweb.net/files/43291 sendaiframeworkfordrren.pdf

United Nations Office for the Coordination of Humanitarian Affairs (2012) Nigeria: floods vol 2. United Nations Office for the Coordination of Humanitarian Affairs (UNOCHA), Abuja. http:// reliefweb.int/sites/reliefweb.int/files/resources/Full\%20Report 1141.pdf

Uzochukwu CE, Ekwugha UP, Marion NE (2014) Media coverage of the environment in Nigeria: issues and prospects. Int J Soc Sci Humanit Rev 4(2):111-124. https://doi.org/10.1080/1533015X.2016. 1164094

van der Werff P (2004) Stakeholder responses to future flood management ideas in the Rhine River Basin: nature or neighbour in Hell's Angle. Reg Environ Chang 4(2-3):145-158. https://doi.org/10. 1007/s10113-004-0073-z

van Eeten M (1997) Policy narratives about flooding and dike improvement. Beleid en Maatschappij 1:55-56

Van Koppen B (2003) Water reform in sub-Saharan Africa: what is the difference? Phys Chem Earth Parts A B C 28(20-27):1047-1053. https://doi.org/10.1016/j.pce.2003.08.022

Vanguard (2013) 2013 Rainfall: anxiety reigns over imminent flood. Vanguard 6 March [online]. Available at https://www.vanguardngr. com/2013/03/2013-rainfall-anxiety-reigns-over-imminent-flood/. Accessed 18 Dec 2016

Vanguard (2016) Abia lacks capacity to handle emergency flood disaster - SSG. Vanguard 26 August [Online]. Available at https://www. vanguardngr.com/2016/08/abia-lacks-capacity-handle-emergencyflood-disaster-ssg/. Accessed 15 Jan 2017)

Viljoen MF, du Plessis LA, Booysen HJ, Weepener HL, Braune M, van Bladeren D, Butler M (2001) Flood damage management aids for 39 integrated sustainable development planning in South Africa. WRC Report No. 889/1/01

Wantu J, Akubo J (2015) Victims of 2012 flood disaster in Lokoja send SOS to governor. Guardian 2 October [Online]. Available at https:// guardian.ng/news/victims-of-2012-flood-disaster-in-lokoja-sendsos-to-governor/. Accessed on 10 Dec 2016

White I, Kingston R, Barker A (2010) Participatory geographic information systems and public engagement within flood risk management. J Flood Risk Manage 3(4):337-346. https://doi.org/10.1111/j.1753318X.2010.01083.X

Wiering MA, Arts BJM (2006) Discursive shifts in Dutch river management: 'deep' institutional change or adaptation strategy? In: Living rivers: trends and challenges in science and management. Springer, 565, 1 p 327-338 https://doi.org/10.1007/s10750-005-5923-2

Wiering M, Kaufmann M, Mees H, Schellenberger T, Ganzevoort W, Hegger DLT, Larrue C, Matczak P (2017) Varieties of flood risk governance in Europe: how do countries respond to driving forces and what explains institutional change? vol 44 15-26. https://doi. org/10.1016/j.gloenvcha.2017.02.006

Wilby RL, Keenan R (2012) Adapting to flood risk under climate change. Prog Phys Geogr 36(3):348-378. https://doi.org/10.1177/ 0309133312438908 